\title{
A SURVEY OF THE FREQUENCIES OF BISTON BETULARIA (L.) (LEP.) AND ITS MELANIC FORMS IN GREAT BRITAIN
}

\author{
Dr H. B. D. KETTLEWELL \\ Genetics Laboratory, Zoology Department, University of Oxford
}

Received 30.iii.57

\section{FOREWORD}

Biston betularia, the Peppered Moth (previously placed in the genera Amphidasys and Pachys), is one of about 70 species of Macrolepidoptera occurring in this country which are at present in the process of changing their populations from light to dark. This is referred to as Industrial Melanism. In nearly every instance it results in the substitution of a complex pattern by a dark or black coloration. Inclustrial melanism is found, in fact, only among those species which depend for their survival by day on their efficiency in harmonising with the specialised background on which they rest, such as lichened trunks, boughs, rocks or wood. It is not found in those species which exhibit other types of protective coloration. The black mutant is nearly always inherited as a simple Mendelian dominant. In compiling a survey, such as the one about to be described, it was necessary to choose a species which had the following attributes:-it must be widespread, forming fairly continuous populations both in industrial and rural areas; it must indulge in considerable periods of flight to encourage gene-flow; and be easy to capture at mercury vapour traps or by other methods. $B$. betularia has all these qualifications. Accordingly, in $195^{2}$ I was fortunate enough to recruit a team of about 80 entomologists (which has since risen to over 150) living in different parts of the country, and to them I owe my sincere thanks for more than 20,000 records of this species which they have sent $\mathrm{mc}$ in the last four years.

\section{THE PHENOTYPES}

Typical $B$. betularia is whitish overlaid with innumerable thin black lines and dots. At rest on lichened boughs it is often almost invisible. The first melanic appeared about 1848 in Manchester (Barrett, I $90 \mathrm{I}$ ), and is referable to as f. carbonaria Jordan (syn. doubledayaria Millière).

Another melanic form is known as insularia Th. Mieg. It is not as extreme as carbonaria and is variable. Occasionally it is difficult to differentiate from the typica form, and still less frequently from carbonaria. These two melanics are not allelomorphic (Kettlewell, 1953). Hitherto there has been no evidence of linkage. There is, 
however, a distinct possibility that $\mathrm{f}$. insularia may be controlled by a series of alleles. The three forms are figured in a previous paper (Kettlewell, I956a). Carbonaria is unifactorial and dominant to the typica form, and insularia, which is also dominant or semi-dominant to the type, cannot be recognised phenotypically in the presence of carbonaria.

\section{PREVIOUS INVESTIGATIONS}

The following facts have been recorded by me and have a direct bearing on the distribution of the three phenotypes in Britain :-

(a) "To the human eye, carbonaria proved much better concealed on the lichen-free tree trunks, blackened by pollution near Birmingham, but this advantage was reversed in favour of the pale form in unpolluted country. Insularia possesses an intermediate advantage in both places" (Kettlewell, 1956a).

(b) Mark-release-recapture experiments showed that in the industrial area of Birmingham we recaptured more than twice as many f. carbonaria as typica in a total release of $5^{84}$ of these two forms. In contrast, a release of 969 individuals into an unpolluted and heavily lichened wood in Dorset resulted in twice as many of the typica form being recaptured as of the $f$. carbonaria. In both experiments, the recaptures were usually made within 24 hours of the release.

(c) This was shown to be due to bird predation. Six species of birds were recorded as taking part in this and filmed as they captured resting moths whilst under observation (by Dr Niko Tinbergen). In Birmingham, Redstarts, Phoenicurus phoenicurus L., were seen to take 58 betularia which had been released in a 1 : I ratio, melanic : typical ; 43 were typica and 15 f. carbonaria. On the other hand, in the unpolluted wood of Dean End, Dorset, when both forms were released in equality, 5 species of birds were observed to eat I9o betularia, of which 164 were f. carbonaria and $26 \mathrm{f}$. typica. These findings provided evidence for stating that "the difference in cryptic coloration alone could be responsible for the rapid spread of the Industrial Melanics"

(d) Nevertheless, we have provided certain basic evidence that there exist both physiological and behaviour differences between the melanic and typical forms (Kettlewell, 1956b).

\section{EARLY HISTORY OF MELANIC SPREAD}

Prior to the middle of the last century, there is every reason to believe that melanic forms were maintained in the population solely by recurrent mutation. For the next fifty years these melanics were much sought after by collectors, so that it is reasonable to suppose that their capture would be recorded assiduously when they first made their appearance. Table I gives a list of the earliest records 
FREQUENCIES OF MELANIG FORM IN BISTON

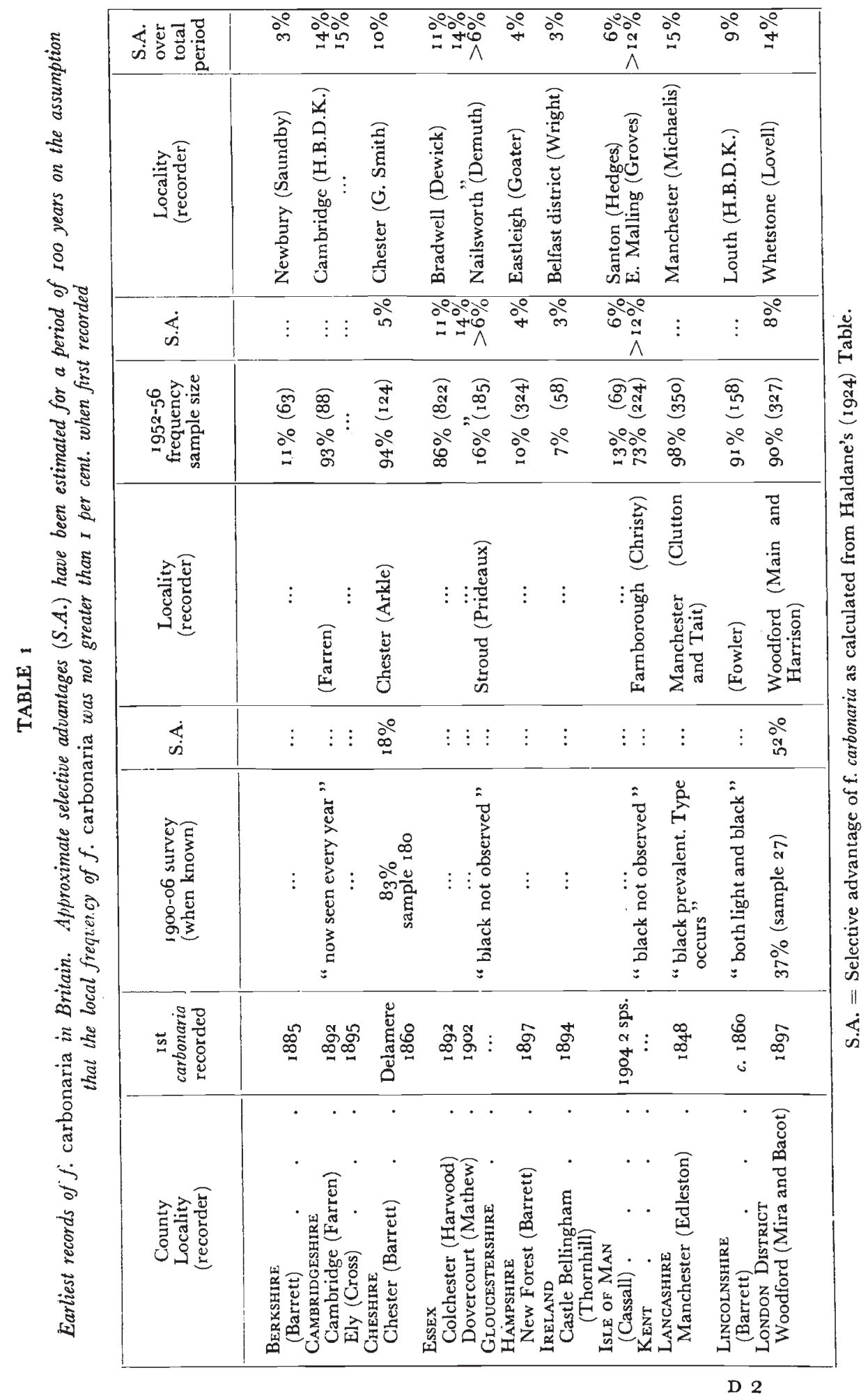




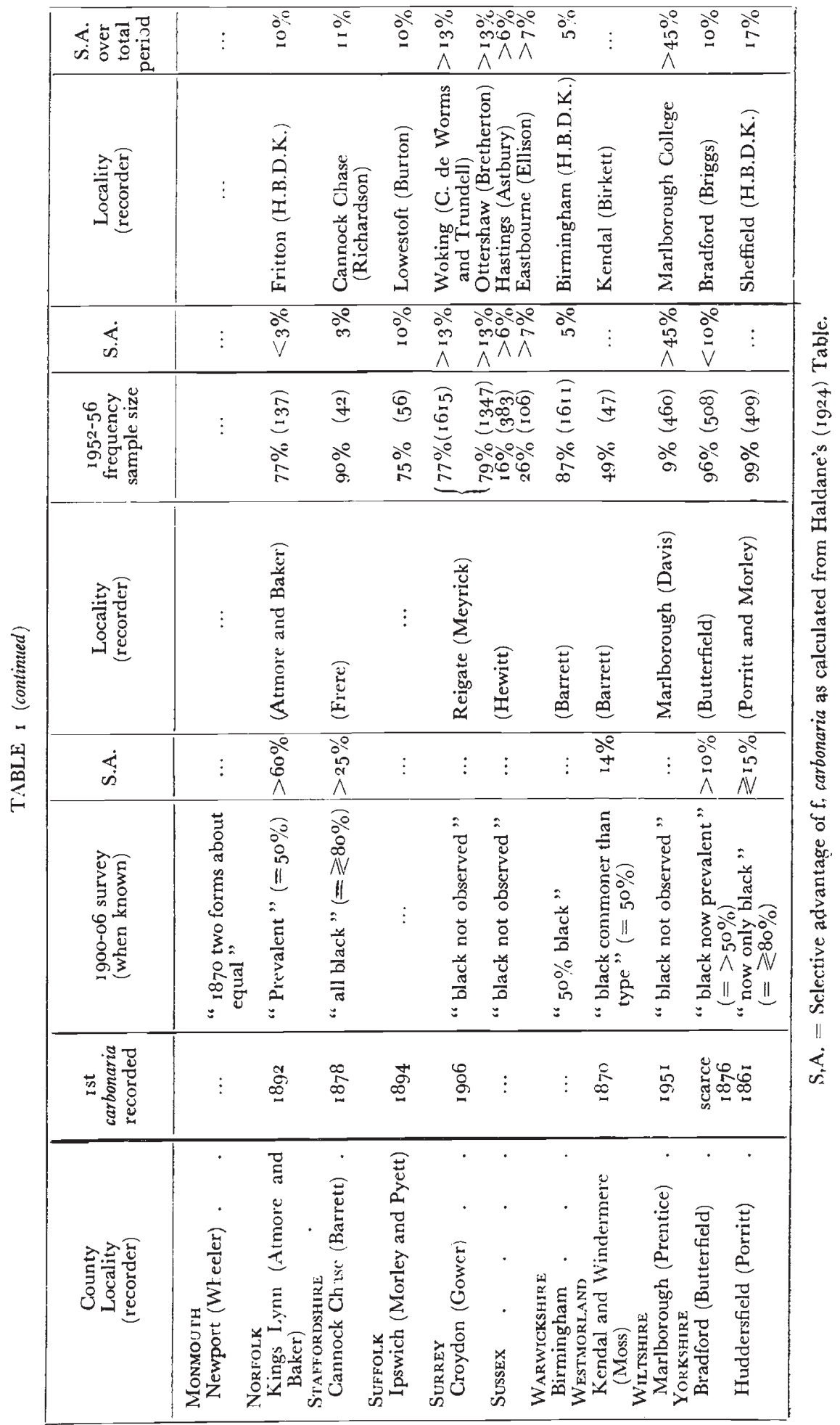


of $f$. carbonarla from different localities, and it has been assumed that at these dates carbonaria would not be at a local frequency higher than say I per cent. In I goo, The Evolution Comnittee of the Royal Society began an investigation into the problem of industrial melanism. It is unfortunate that approximate percentages only are given (Doncaster, I9o6), but by this date scientific opinion had evidently become conscious of the biological importance of the rapid spread of the melanic forms. Only on two occasions, in fact, are there actual figures for random samples. The same unfortunate shortcomings are found in the later investigations of Mera (1925) and Adkin (1925). In fact nowhere are the figures given which would have helped so much in the present investigation.

Certain information can, however, be deduced from these earlier records. It appears that $\mathrm{f}$. carbonaria was taken for the first time in many widely separated places between 1848 and igoo. Whether this represents migration from one centre, or numerous discrete mutations, will be discussed later. Secondly, very shortly after the initial captures this melanic form increased rapidly in a brief space of time. Thirdly, until the end of the century, carbonaria was unknown in southern England. At this time it had a midland and eastern county distribution and was not taken in the London area till i 897 . Fourthly, when these earliest records are considered with our recent data, the selective advantages (p. 64) for the carbonaria form can, with a reasonable degree of accuracy, be assessed for each locality over the period involved. The ability to do this in one of the most transient polymorphisms ever known, makes these earliest records most valuable.

\section{PRESENT SURVEY}

In view of the inadequate nature of the data on the frequencies of the melanic forms at any one period in the past, I decided in $195^{2}$ to obtain as much data on betularia as quickly as possible, with the object of providing figures for future reference. At the same time, a great deal of information has been collected, some of which is capable of being analysed at present.

Table 2 gives a list of frequencies of the three forms of betularia from many areas of Great Britain. Furthermore, the last column gives the estimated true frequency of insularia in the non-carbonaria fraction of the population (assuming no linkage), carbonaria being epistatic to this form. It will be appreciated that the higher the frequency of carbonaria, the greater the error in assessing the insularia frequency, and that even in large random samples from industrial areas the data are often inadequate. 
TABLE 2

Phenotype frequencies of Biston betularia and its two melanics, $f$. carbonaria and $f$. insularia, from 83 centres in Britain (1952-56)

\begin{tabular}{|c|c|c|c|c|c|c|}
\hline Locality & Observer & $\begin{array}{l}\text { Per } \\
\text { cent. } \\
\text { T }\end{array}$ & $\begin{array}{l}\text { Per } \\
\text { cent. } \\
\text { C }\end{array}$ & $\begin{array}{l}\text { Per } \\
\text { cent. } \\
\text { I }\end{array}$ & Total & $\begin{array}{l}\text { Estimated } \\
\text { frequency } \\
\text { per cent. I }\end{array}$ \\
\hline BEDFORDSHIRE & & & & & & \\
\hline $\begin{array}{l}\text { Woburn } \\
\text { Leighton Buzzard }\end{array}$ & $\begin{array}{l}\text { S.H.K. } \\
\text { J.F.R. }\end{array}$ & $\begin{array}{r}4 \cdot 76 \\
15 \cdot 43\end{array}$ & $\begin{array}{l}95 \cdot 23 \\
82 \cdot 28\end{array}$ & $\begin{array}{l}0 \\
2 \cdot 29\end{array}$ & $\begin{array}{r}21 \\
175\end{array}$ & $\begin{array}{l}0 \\
12 \cdot 90\end{array}$ \\
\hline $\begin{array}{l}\text { BERKSHIRE } \\
\text { Newbury }\end{array}$ & R.S. & $79 \cdot 37$ & $I I \cdot I I$ & $9 \cdot 5^{2}$ & 63 & 10.71 \\
\hline $\begin{array}{c}\text { CAMBRIDGESHIRE } \\
\text { Cambridge . }\end{array}$ & $\left.\begin{array}{l}\text { H.B.D.K. } \\
\text { B.O.C.G. }\end{array}\right\}$ & $4 \cdot 54$ & $9^{2} \cdot 95$ & $3 \cdot 4^{I}$ & 88 & $4^{2} \cdot 85$ \\
\hline $\begin{array}{ll}\text { CHESHIRE } \\
\text { Chester } \\
\text { Delamere } \\
\text { Heswall } \\
\text { Wirrall } & : \\
\end{array}$ & $\begin{array}{l}\text { S.G.S. } \\
\text { W.E.A. } \\
\text { D.E.H. } \\
\text { A.C. }\end{array}$ & $\begin{array}{l}5 \cdot 65 \\
6 \cdot 68 \\
6 \cdot 82 \\
1 \cdot 56\end{array}$ & $\begin{array}{l}93 \cdot 55 \\
90 \cdot 86 \\
93 \cdot 18 \\
98 \cdot 44\end{array}$ & $\begin{array}{l}0 \cdot 81 \\
2 \cdot 4^{6} \\
0 \\
0\end{array}$ & $\begin{array}{r}124 \\
569 \\
44 \\
192\end{array}$ & $\begin{array}{l}12 \cdot 50 \\
26 \cdot 92 \\
0 \\
0\end{array}$ \\
\hline $\begin{array}{l}\text { Cumberland } \\
\text { Penrith }\end{array}$ & W.F.D. & $60 \cdot 7 \mathrm{I}$ & $26 \cdot 79$ & $12 \cdot 50$ & $5^{6}$ & $17 \cdot 07$ \\
\hline $\begin{array}{l}\text { Derbyshire } \\
\text { Chesterfield . }\end{array}$ & J.H.J. & $0 \cdot 59$ & $99^{\circ} 4^{I}$ & o & 170 & o \\
\hline $\begin{array}{l}\text { DEvON and CoRNwaLL } \\
\text { Torquay } \\
\text { Ashburton }: \\
\text { Bude } \\
\text { Plymouth } \\
\text { Tavistock }: \\
\text { Tiverton }: \\
:\end{array}$ & $\begin{array}{l}\text { F.H.L. } \\
\text { S.T.S. } \\
\text { A.H. } \\
\text { F.W.J. } \\
\text { D.J.W. } \\
\text { F.H.L. }\end{array}$ & 100 & 0 & o & 100 & o \\
\hline $\begin{array}{l}\text { DORSET } \\
\text { Dean End Wood } \\
\text { Broadmayne. }\end{array}$ & $\begin{array}{l}\text { H.B.D.K. } \\
\text { V.W.P. }\end{array}$ & $\begin{array}{l}93^{\cdot 64} \\
97^{\circ} 02\end{array}$ & $\begin{array}{l}0.87 \\
0\end{array}$ & $\begin{array}{l}5 \cdot 49 \\
2 \cdot 98\end{array}$ & $\begin{array}{l}346 \\
168\end{array}$ & $\begin{array}{l}5 \cdot 54 \\
2 \cdot 98\end{array}$ \\
\hline $\begin{array}{l}\text { Essex } \\
\text { Bradwell on Sea } \\
\text { Westcliffe on Sea }\end{array}$ & $\begin{array}{l}\text { A.J.D. } \\
\text { H.C.H. }\end{array}$ & $\begin{array}{l}6 \cdot 69 \\
5 \cdot 95\end{array}$ & $\begin{array}{l}86 \cdot 25 \\
85 \cdot 55\end{array}$ & $\begin{array}{l}6 \cdot 57 \\
8 \cdot 5\end{array}$ & $\begin{array}{l}818 \\
353\end{array}$ & $\begin{array}{l}49 \cdot 54 \\
58 \cdot 82\end{array}$ \\
\hline $\begin{array}{l}\text { GLOUCESTERSHIRE } \\
\text { Hardwicke : } \\
\text { Nailsworth : }\end{array}$ & $\begin{array}{l}\text { R.D. } \\
\text { A.R. }\end{array}$ & $\begin{array}{l}3^{8 \cdot 89} \\
4^{8 \cdot 6} \cdot 6\end{array}$ & $\begin{array}{l}23 \cdot 61 \\
15 \cdot 68\end{array}$ & $\begin{array}{l}37.5 \\
35.67\end{array}$ & $\begin{array}{r}72 \\
185\end{array}$ & $\begin{array}{l}49^{\cdot 09} \\
4^{2} \cdot 3^{1}\end{array}$ \\
\hline $\begin{array}{l}\text { HAMPSHIRE } \\
\text { Bournemouth } \\
\text { Chandler's Ford } \\
\text { Borden } \\
\text { Fordingbridge } \\
\text { Winchester } \\
\text { Fleet } .\end{array}$ & $\begin{array}{l}\text { F.M.B.C. } \\
\text { B.G. } \\
\text { D.W. } \\
\text { P.J.B. } \\
\text { R.S.M.W. } \\
\text { A.W.R. }\end{array}$ & $\begin{array}{l}60 \cdot 00 \\
82 \cdot 1 \\
65 \cdot 43 \\
86 \cdot 84 \\
84 \cdot 85 \\
47 \cdot 31\end{array}$ & $\begin{array}{r}30 \cdot 00 \\
10 \cdot 49 \\
20 \cdot 29 \\
5 \cdot 26 \\
15 \cdot 15 \\
46 \cdot 03\end{array}$ & $\begin{array}{r}10 \cdot 00 \\
7.41 \\
14.28 \\
7 \cdot 89 \\
\ldots .66\end{array}$ & $\begin{array}{r}40 \\
324 \\
3095 \\
38 \\
33 \\
315\end{array}$ & $\begin{array}{r}14 \cdot 29 \\
8 \cdot 27 \\
\mathrm{I} 7 \cdot 92 \\
8 \cdot 33 \\
0 \\
12 \cdot 35\end{array}$ \\
\hline $\begin{array}{l}\text { HEREFORDSHIRE } \\
\text { Malvern }\end{array}$ & R.K.J. & $46 \cdot 30$ & $27 \cdot 80$ & $25 \cdot 90$ & 54 & $35 \cdot 90$ \\
\hline $\begin{array}{l}\text { HERTFORDSHIRE } \\
\text { Bishops Stortford } \\
\text { Rothamsted . } \\
\text { Tring . }\end{array}$ & $\begin{array}{l}\text { C.C. } \\
\text { C.B.W. } \\
\text { L.G. }\end{array}$ & $\begin{array}{r}4 \cdot 76 \\
\text { I I } 08 \\
\text { I } 6 \cdot 89\end{array}$ & $\begin{array}{l}89 \cdot 18 \\
83 \cdot 69 \\
74 \cdot 30\end{array}$ & $\begin{array}{l}6 \cdot 06 \\
5 \cdot 23 \\
9 \cdot 81\end{array}$ & $\begin{array}{l}231 \\
325 \\
214\end{array}$ & $\begin{array}{l}56 \cdot 01 \\
32 \cdot 08 \\
38 \cdot 18\end{array}$ \\
\hline
\end{tabular}


TABLE 2 (continued $\left.d^{\prime}\right)$

\begin{tabular}{|c|c|c|c|c|c|c|c|c|}
\hline Locality & & & Observer & $\begin{array}{c}\text { Per } \\
\text { cent. } \\
\text { T }\end{array}$ & $\begin{array}{l}\text { Per } \\
\text { cent. } \\
\text { C. }\end{array}$ & $\begin{array}{l}\text { Per } \\
\text { cent. } \\
\text { I }\end{array}$ & Total & $\begin{array}{l}\text { Estimated } \\
\text { frequency } \\
\text { per cent. I }\end{array}$ \\
\hline IRELAND & & & & & & & & \\
\hline Belfast distric & $c t$ & - & W.S.W. & $93 \cdot 10$ & $6 \cdot 90$ & $\cdots$ & $5^{8}$ & o \\
\hline Dublin distri & & . & E.S.A.B. & $96 \cdot 30$ & $3 \cdot 70$ & $\ldots$ & 27 & o \\
\hline ISLE OF MAN & & & & & & & & \\
\hline Santon & . & · & A.H. & $50 \cdot 70$ & I $3 \cdot$ I I & $3^{6 \cdot 20}$ & 69 & $4^{1 \cdot 67}$ \\
\hline ISLE OF WIGHT & & & & & & & & \\
\hline Freshwater & • & - & K.E.B. & $\cdots$ & $\cdots$ & $\cdots$ & $5^{\circ}$ & $\cdots$ \\
\hline KENT & & & & & & & & \\
\hline Bromley & . & . & M.G.M. & $9 \cdot 26$ & $88 \cdot 89$ & $I \cdot 85$ & 54 & I $6 \cdot 66$ \\
\hline Folkestone & . & · & A.M.M. & $46 \cdot 43$ & $42 \cdot 86$ & $10 \cdot 71$ & 140 & $19 \cdot 75$ \\
\hline East Malling & & · & D.E. & $\cdots$ & $\ldots$ & $\cdots$ & $\cdots$ & $\cdots$ \\
\hline Maidstone & $\cdot$ & . & J.R.G. & $2 I \cdot 43$ & $73 \cdot 21$ & $5 \cdot 36$ & 224 & $20 \cdot 00$ \\
\hline LANCASHIRE & & & & & & & & \\
\hline $\begin{array}{l}\text { Formby } \\
\text { Southport }\end{array}$ & - & - & N.G.L. & $\begin{array}{r}5 \cdot 32 \\
10 \cdot 00\end{array}$ & $94^{\cdot 68}$ & $\cdots$ & $\begin{array}{r}94 \\
120\end{array}$ & $\begin{array}{l}0 \\
0\end{array}$ \\
\hline $\begin{array}{l}\text { Southport } \\
\text { Manchester }\end{array}$ & $\cdot$ & . & K.L.G. & $\begin{array}{l}10 \cdot 00 \\
0\end{array}$ & $\begin{array}{l}90 \cdot 00 \\
98 \cdot 00\end{array}$ & $\ddot{2} \cdot 00$ & 350 & I 00 \\
\hline LEICESTERSHIRE & & & & & & & & \\
\hline Market Hark & borougl & & H.A.B. & II $\cdot 83$ & $84 \cdot 95$ & $3 \cdot 3^{2}$ & 93 & $21 \cdot 43$ \\
\hline LINCOLNSHIRE & & & & & & & & \\
\hline Grimsby & . & . & G.A.T.J. & $7 \cdot 41$ & $88 \cdot 89$ & $3 \cdot 75$ & 81 & $33 \cdot 35$ \\
\hline Louth & · & · & H.B.D.K. & $6 \cdot 33$ & $9 \mathrm{I} \cdot \mathrm{I} 3$ & $2 \cdot 53$ & I $5^{8}$ & $28 \cdot 57$ \\
\hline LONDON AREA & & & & & & & & \\
\hline Whetstone & $\cdot$ & - & R.L. & $5 \cdot 8 \mathrm{I}$ & $90 \cdot 21$ & $3 \cdot 9^{8}$ & 327 & $40 \cdot 63$ \\
\hline Middlesex & & & & & & & & $39 \cdot 28$ \\
\hline Pinner . & - & - & W.E.M. & $9^{\cdot 1} 4$ & $84 \cdot 95$ & $5 \cdot 9^{1}$ & $55^{8}$ & $39^{\circ 28}$ \\
\hline NORFOLK & & & & & & & & \\
\hline Cromer & - & - & J.B. & $20 \cdot 93$ & $67 \cdot 44$ & I I $\cdot 63$ & 43 & $35 \cdot 71$ \\
\hline Fritton & $\cdot$ & $\cdot$ & H.B.D.K. & $14 \cdot 60$ & $77 \cdot 37$ & $8 \cdot 03$ & I 37 & $35^{\circ} 4^{8}$ \\
\hline Northants & & & & & & & & \\
\hline Wellingboro & ugh & · & P.J.G. & $14 \cdot 24$ & $79 \cdot 88$ & $5 \cdot 90$ & 288 & $29 \cdot 31$ \\
\hline OXFORDSHIRE & & & & & & & & \\
\hline Oxford distr & & . & $\left.\begin{array}{l}\text { H.B.D.K. } \\
\text { P.M.S. } \\
\text { G.V. }\end{array}\right\}$ & $4^{1} \cdot 00$ & $34^{\cdot 03}$ & $24 \cdot 97$ & 717 & $37 \cdot 84$ \\
\hline Steeple Bartc & & • & H.B.D.K. & $49^{\cdot} \cdot 13$ & $34 \cdot 26$ & $\mathrm{I} 6 \cdot 6 \mathrm{I}$ & 289 & $25 \cdot 26$ \\
\hline Scotland & & & & & & & & \\
\hline Glasgow & $\cdot$ & . & H.B.D.K. & $10 \cdot 33$ & $89 \cdot 66$ & $\cdots$ & 29 & $\cdots$ \\
\hline $\begin{array}{l}\text { Kinloch Rar } \\
\text { Newtonmore }\end{array}$ & noch & · & R.L. & I 00 & $\cdots$ & $\cdots$ & 285 & $\cdots$ \\
\hline Newtonmore & & - & G.H. & 100 & $\cdots$ & $\cdots$ & & $\cdots$ \\
\hline SOMERSET & & & & & & & & \\
\hline Portishead & · & $\cdot$ & J.A.B. & $50 \cdot 00$ & $20 \cdot 00$ & $30 \cdot 00$ & Io & $375^{\circ}$ \\
\hline SuFFoLK & & & & & & & & \\
\hline $\begin{array}{l}\text { Beccles } \\
\text { Lowestoft }\end{array}$ & · & . & $\begin{array}{l}\text { E.T.G. } \\
\text { J.B. }\end{array}$ & I $7 \cdot 86$ & $75 \cdot 00$ & $7 \cdot 14$ & $5^{6}$ & $28 \cdot 57$ \\
\hline
\end{tabular}


TABLE 2 (rontinued $\rangle$

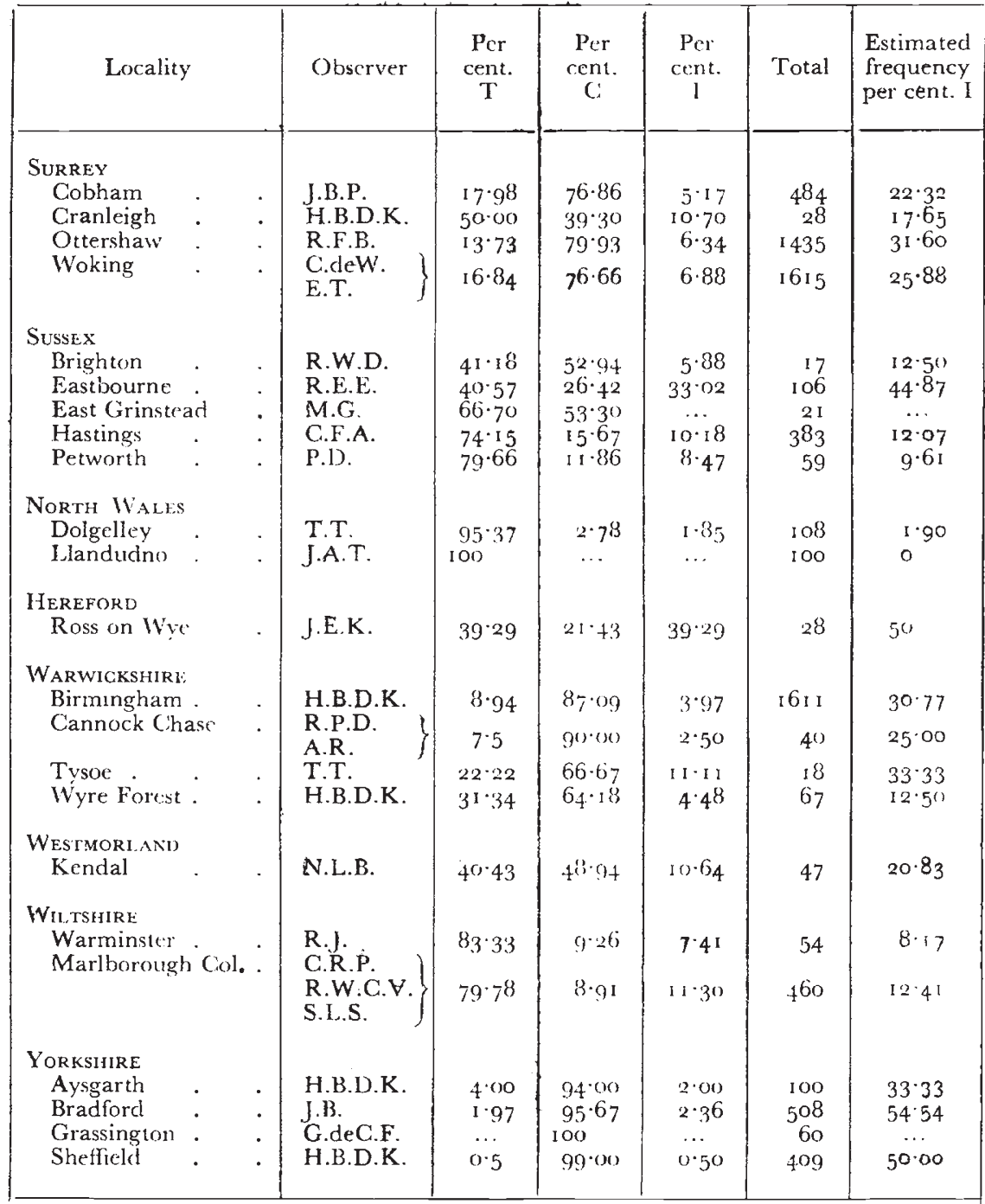

Throughout this paper the letters T, C, I stand for Biston betularia f. typica, f. carbonaria and f. insularia respectively.

A distribution map (fig. I) of the frequencies of the three forms shows :

(a) A correlation between the frequency of the melanic forms and the industrial areas of Britain.

(b) A high frequency of carbonaria throughout eastern England from north to south, though far removed from industrial centres. This is, in my opinion, the indirect effect of long continued smokc fall-out carried by the prevailing south-westerly winds from central England. 
(c) Western Britain, with the exception of Cheshire, Lancashire and Westmorland (Kendal) is virtually melanic free.

(d) Northern Scotland has no melanic betularia but in the Glasgow district $f$. carbonaria is about 90 per cent.

(e) In Ireland, carbonaria has been recorded, first in 1894 from the Belfast district and aso Dublin, but is of rare occurrence. It has been found nowhere else.

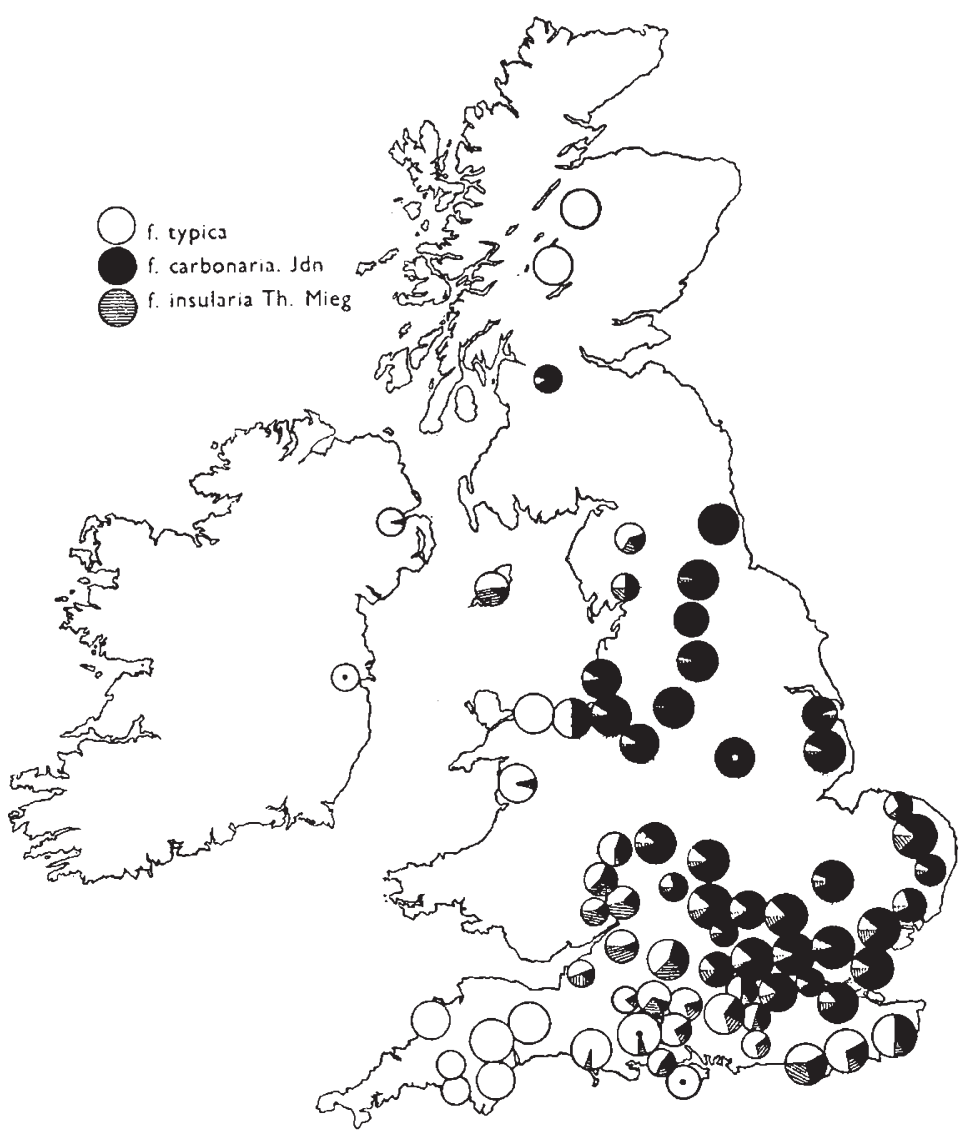

Fic. 1.-A fiequency map of Biston betularia and its two melanics, $\mathrm{f}$. carbonaria and $\mathrm{f}$. insularia (1952-56), comprising more than 20,000 records from 83 centres in Britain.

(f) The map shows multiple clines running out from the higher carbonaria frequencies in the centre of England. There may be a rapid decline from east to west as, for instance, from Cheshire to North Wales, or from Birmingham to Wyre Forest, or they may be gradual as always found in an easterly direction.

$(g)$ The highest frequency of f. insularia phenotype is, for the most part, found in the Gloucester and Severn Valley district of England. 


\section{ANALYSIS OF F. CARBONARIA FREQUENCIES}

\section{(a) Evidence of mutation rate}

If one reviews the first county records, it is indeed difficult to resist the conclusion that the new mutant has radiated outwards from an original centre of mutation near Manchester. There is no doubt that following the original capture in 1848 , the nearest counties to Lancashire were the next to record its appearance; Cheshire in 1860, Yorkshire in 186r, Staffordshire in 1878, and Westmorland in 1870. The London district, on the other hand, and southern England did not report a carbonaria until about twenty years later [1897). It is significant also that the eastern counties of Norfolk, Suffolk and Cambridge all recorded their first carbonaria practically simultaneously between 1892 and 1895 .

All this is consistent with the spread of a successful gene with no ecological barriers, from its centre of origin. Furthermore, on the Continent, the same spread was taking place, being recorded by A. Hofmann from Hanover in 1884, the Netherlands and Thuringia in 1888 " and in the next few years in various parts of the Rhine Valley, indeed he [Hofmann] thinks that its progress was up the Rhine" (Barrett, I90 I).

In a short series of evening releases undertaken in open country near Louth, Lincs., in 1956 I attempted to find the distance which betularia flies per night. Using different releasing points, different markings, and several collecting centres of known distance apart, I was able to show that of 93 releases, 6 travelled $1 \frac{1}{2}$ miles, and 9 over half a mile within 48 hours. At Fritton in Suffolk, of 78 releases over three occasions, I 6 were recaptured three-quarters of a mile distant, I 2 within 24 hours. From this, having regard to the random flight of the releases, it can be accepted that betularia frequently flies a mile per night, probably much farther. Nevertheless, dispersal cannot be accepted as the actual cause of the widespread distribution of $f$. carbonaria. There is considerable evidence that recurrent mutation, at a fairly high rate, also takes place. Carbonaria has constantly appeared in isolated centres separated from others by usually impassable barriers. Thus it was taken in Dublin about 1950, near Belfast in 1894, the Isle of Man in 1904, and in 1956 at Torquay, each locality being separated by fifty miles or more from the nearest possible contacts. It is, in fact, likely that the carbonaria allele has a high mutation rate. This is in contrast with certain melanics of other species, such as f. nigra of Ectropis consonaria. In this country, only on two occasions has the melanic mutation successfully maintained itself, first near Maid tone in Kent, and secondly near Stroud, Gloucestershire, where a sample of 121 recorded by me in $195^{6}$ were 43 per cent. of the melanic form. It would appear that this melanic mutation has not yet taken place in an industrial centre in this country. It has, however, in Germany where it has become an industrial melanic. 
(b) Period of adjustment

Haldane (1924) has pointed out that if in Manchester in 1848 the betularia population was 99 per cent. the typica form, and if by 1898 it was 99 per cent. f. carbonaria, this represents an approximate 30 per cent. advantage of the black form over the light. Magnitudes, only rather less than this, are borne out by table $\mathrm{I}$.

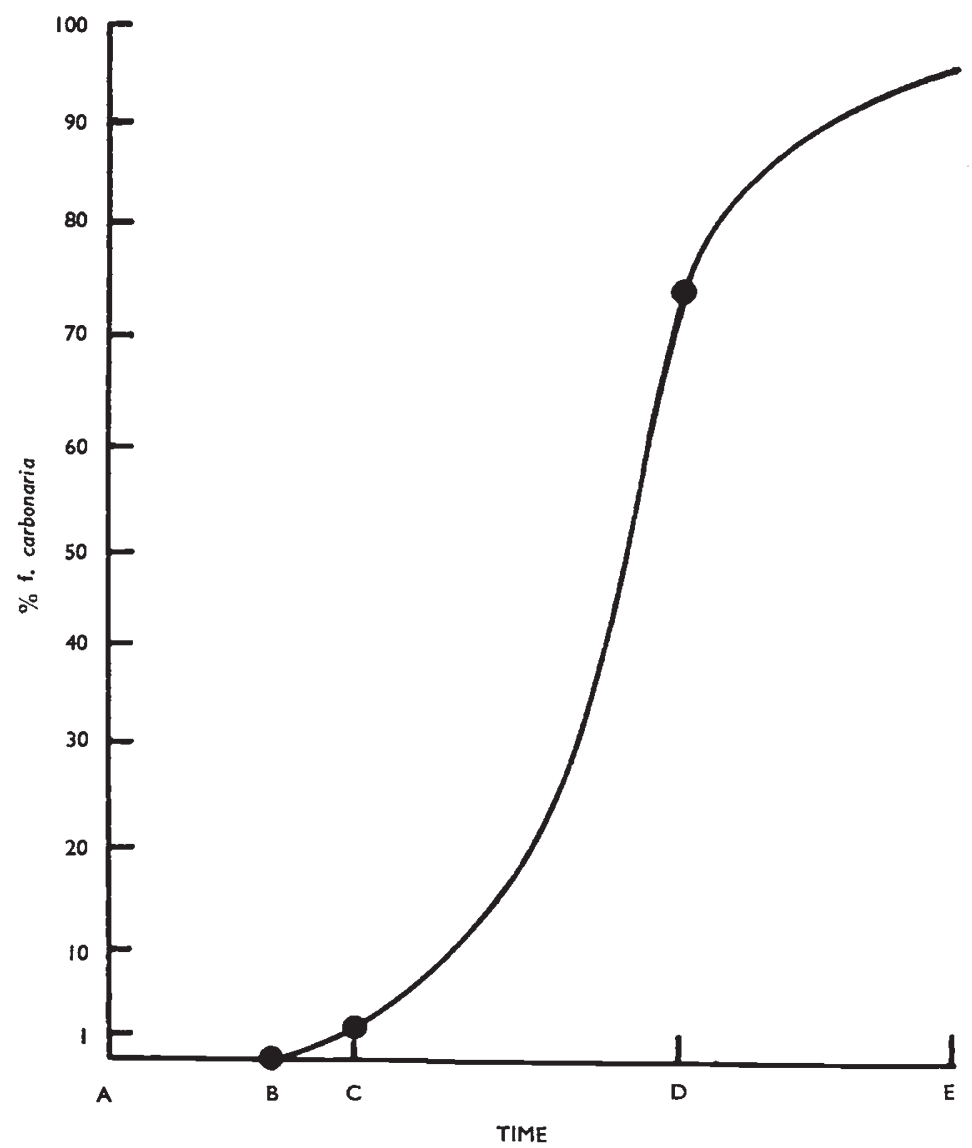

FIti. 2.-Diagram showing rate of increase of a melanic (dominant) mutant with a mutation rate of one in a million, assuming a constant advantage of the heterozygote throughout (which in practice will not occur), with a 30 per cent. selective advantage over its typical form.

It is now necessary for us to consider, therefore, the time lag between the original mutation and its arrival at the I per cent. level. At frequencies below this, it is unlikely to have been recognised in the population because of the poorer techniques in sampling used at that date. Let us examine an hypothetical case and assume that in a local population of the order of a million, a single melanic mutation has occurred. With a 30 per cent. advantage, it would take about 29 years to reach the $0^{\cdot I}$ per cent. level, and 38 years to I per cont. Fig. 2 is a diagram showing the type of spread expected from a new 
mutant from the time of its origin until it has reached a state of balanced polymorphism or, alternatively, has eliminated its allele from the population. Present data are in agreement with this type of curve. The period under present consideration is represented by $\mathrm{BC}$ on the abscissa, and if, in fact, there was only one mutation in Manchester, and by 1848 carbonaria has reached i per cent. of the population, we can say that this original mutation took place in about 18 Io, which is approximately fifty years after the commencement of the Industrial Revolution.

During this initial period (BC), the black mutants, though having great cryptic advantage, nevertheless would find themselves in a gene-complex entirely fitted for the specialised pattern of the typica form. It is of interest that many of the earliest examples of $f$. carbonaria which I have obtained by searching innumerable old collections, are different from the majority of heterozygous carbonaria found to-day. Plate I shows two rows of probable heterozygous carbonaria, the righthand one of which is comprised of insects, all of which were caught in the last century. They bear no resemblance to f. insularia. In contrast, the left-hand column shows five modern heterozygotes, and it will be noted that they differ considerably from those collected seventy years previously. Many of the earliest specimens show white markings on all the wings in both sexes greatly in excess of what are generally found to-day. The present-day heterozygote only occasionally shows minor degrees of white markings on the wings. On the other hand, the majority of carbonaria have white dots around the head and at the base of the wings. In the Sheffield area and, to a lesser degree, in other centres (Chester for example), these spots are also disappearing in present-day specimens, leaving a completely black insect. This must be brought about by modifying genes through the effect of natural selection. It provides evidence that during this period the gene-complex was adjusting itself to attain its greatest advantage. Furthermore, it suggests that in the early days f. carbonaria had not full dominance. We are at present attempting to verify this by outcrossing carbonaria into West Country stock whose complex has had no experience of this mutant.

Of even more interest is the situation I have recently found in regard to physiological advantages and disadvantages. It is accepted among lepidopterists that nowadays an excess of mclanics occur in backcross broods. Table $3^{b}$ gives a list of my own results of backcross betularia broods fed on unwashed Oxford Sallow (Salix sp.) which corroborates this fact. It will be seen that there is a significant excess of melanics. In contrast to this, Doncaster (Igo6) records figures which deviate in the opposite direction for backcross broods occurring between 1900 and 1906 (table $3 a$ ). It is probable that these also were fed on unwashed foliage. Both sets of data are homogeneous but are significantly different. (The $\chi^{2}{ }_{(1)}$ is 13.27 .) It appears, therefore, that in its early phases, the melanic mutant was not at a physiological 
advantage to the typica, and that only after a considerable period of adjustment did it become so. It is possible then that certain major modifying genes, previously adapted for keeping the complicated typical pattern in check, freed from cryptic responsibilities, were now

TABLE 3

A comparison between early and recent backcross broods of Biston betularia segregating for typica and carbonaria showing a deficiency of the two forms in opposite directions

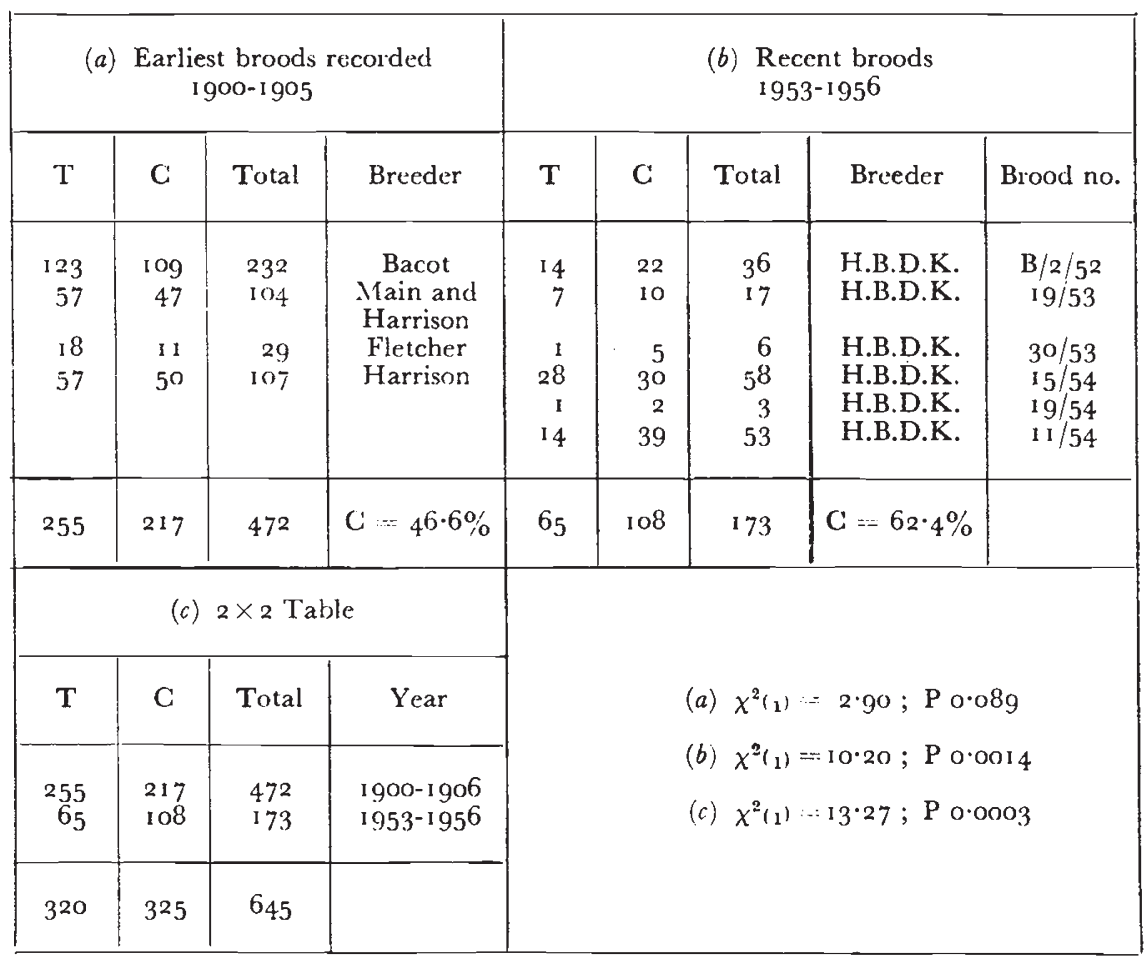

able to exploit themselves in bringing about the best physiological advantage. This period then (BC) must be regarded as a time during which the gene-complex was adjusting itself to the new mutant. The disappearance of a complicated pattern may make it easier for alleles, previously adjusted to this end, to contribute more in other directions.

\section{(c) Period of rapid spread}

In theory, when once adjusted, the new mutant is free to spread, provided the selective pressure is maintained. As in the earlier periods, because backcross matings will leave a higher percentage of melanic offspring, this increase will proceed with great rapidity up to a time when 50 per cent. of the population is of the carbonaria form, and thereafter it will tend to slow down at a speed directly proportionate 
to the increasing carbonaria frequency when the number of heterozygotes in the population will commence to drop as pointed out by Fisher (1937). If we review the progress of carbonaria frequencies in those few localities (table 4) where it stands between I and 40 per cent. for the short time they have been under observation, there are, indeed, indications of rapid spread. In each, it will be seen that the carbonaria frequency has risen significantly. It is, however, possible that the very high selective advantage, apparent in the Marlborough figures, may be due to the initial sample being inadequate. This period of rapid spread is shown on the graph (fig. 2) as GD during which, under certain conditions, it is probable that f. carbonaria can change from being ro per cent. of the local population to 70 per cent. within a period of ten to fifteen years, which reflects accordingly a minimum selective advantage of from 35 to 23 per cent.

\section{(d) Period of slow elimination of $f$. typica or alternatively a balanced polymorphism}

The data in table 2 show that in every industrial area f. carbonaria is now at least 85 per cent., but in no large sample is the value roo per cent. Even after one hundred years, Manchester and Sheffield still have I-2 per cent. of non-carbonaria forms, and Lincolnshire 9 per cent. Furthermore, the only actual sample figures available are for Chester, which show that $\mathrm{f}$. carbonaria rose in the last fifty years from 83 to 94 per cent. only, giving a selective advantage of 5 per cent., after having achieved the earlier frequency from I per cent. in forty-five years (= selective advantage is per cent.). All the available evidence goes to show that f. typica continues in the population however great are the apparent selective pressures against it. This period is referred to as DE in the diagram (fig. 2), and may represent many hundreds of years, depending on unknown variables. It is probable that by now, after experiencing one hundred generations, the new mutant will have succeeded in achieving a gene-complex suitable for its optimum expression, and that by this time the heterozygote will be at an advantage to both the homozygotes. This will have been brought about by Natural Selection. Modifying genes, disadvantageous in the homozygous state, but advantageous as heterozygotes, will have become more closely linked to the new mutant and one would probably find a figure below the expected $3:$ I ratio as the result of heterozygous pairings in the wild, because of the elimination of the homozygous carbonaria. This will inevitably be followed by a balanced polymorphism.

As a corollary of this, it can be anticipated that the rare f. typica, being eliminated on nearly every occasion because of its conspicuousness, and now finding itself in a gene-complex no longer adapted to it but to the melanic, should, in theory, diverge from its previous fixed pattern. I have, therefore, recently commenced to collect all 
the f. typica from districts where it occurs at a very low frequency. With the small numbers at present available, and the difficulty in analysing the degree of divergence, all that can be stated is that considerable variation does occur. Whether this is more than is found in samples from districts where f. carbonaria is absent, I am so far unable to tell.

\section{Conclusions on carbonaria frequencies}

The autocatalytic or sigmoid curve, suggested by Haldane (I924) as representing the likely course of spread of $f$. carbonaria, has been fully borne out. The present investigation shows selective advantages for this mutant of a slightly lower magnitude than that suggested by him, and this, no doubt, reflects more accurate data for present-day frequencies than were available to him. Alternatively, an apparent lower selective advantage would be brought about if a stable polymorphism was taking place in populations with a high frequency of f. carbonaria.

\section{ANALYSIS OF F. INSULARIA FREQUENCIES}

The early history of f. insularia is unsatisfactory in every respect. It is generally agreed that it appeared about the same time as $f$. carbonaria, but in certain districts, particularly in the south, before it. Doncaster (I go6) tried to differentiate "two distinct forms", a light and a dark, and he may in fact be correct. Furthermore, the earlier breeders were confused on finding that backcross carbonaria $\times$ typica broods, on some occasions, "produced intermediates" (= insularia), whilst on others Mendelian segregation took place (Doncaster, I 906).

Insularia occurred in Ireland in I 894, in Scotland (Kincardine) some time prior to I 906 , and was found at the end of the last century in most central industrial areas. It was recorded on the Continent (Belgium) in 1886. All observers agree that it is an industrial melanic, and that it gets rarer following the upsurge of carbonaria.

It is not surprising that $\mathrm{f}$. insularia, being intermediate in appearance between f. typica and f. carbonaria, is found most frequently at the present time on the periphery of industrial areas, outside centres with a high frequency of carbonaria, in whose presence it is impossible to detect phenotypically. Background scoring efficiency (Kettlewell, I 955), for the few releases undertaken by me, give insularia a position intermediate between f. typica and f. carbonaria in both industrial and rural environments. It is, in fact, admirably suited for resting on boughs covered with Pleurococcus and not lichens. Nevertheless, it must be pointed out that, in contrast with carbonaria, the phenotype frequency of insularia has never been found higher than 40 per cent.

Insularia has the great drawback, previously referred to, that it varies from those individuals which are indistinguishable from $f$. typica to those which are as dark as f. carbonaria. The frequency figures, unlike those for f. carbonaria, are, therefore, subject to personal error. 
To estimate this variability, four observers, all living within three miles of each other, and each rated as a most reliable lepidopterist, have supplied independent data over the last few years. It is clear from the table that the estimates of curbonaria percentages do not differ very markedly. Comparing the four values by use of a $2 \times 4$ contingency table does, in fact, disclose some heterogeneity, since $\chi_{(3)}^{2}=7 \cdot 88$, and the 5 per cent. point is $7 \cdot 8 \mathrm{I}$. Although this is formally significant, it does not contradict the view that variations between observers are probably small in respect of carbonaria classifications, since the total sample size of 3534 is large enough to detect very small differences.

\begin{tabular}{|c|c|c|c|c|c|}
\hline \multicolumn{6}{|c|}{ Percentage phenotypes } \\
\hline $\mathrm{T}$ & C: & I & Total & Name & $\begin{array}{l}\text { I. } \\
\text { estimated } \\
\text { frequency }\end{array}$ \\
\hline 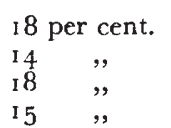 & $\begin{array}{l}77 \text { per cent. } \\
80 \quad, \\
78 \quad " \\
74 \quad "\end{array}$ & $\begin{array}{l}5 \text { per cent. } \\
6 \quad, \\
4 \quad, \\
\text { I I }\end{array}$ & $\begin{array}{r}484 \\
1435 \\
1191 \\
424\end{array}$ & $\begin{array}{l}\text { J.B.P. } \\
\text { R.F.B. } \\
\text { C.deW. } \\
\text { E.T. }\end{array}$ & $\begin{array}{l}22 \cdot 32 \\
31 \cdot 60 \\
18 \cdot 80 \\
40 \cdot 54\end{array}$ \\
\hline
\end{tabular}

To make a similar test for insularia, we have examined the $2 \times 4$ contingency table based on the insularia and typica figures. (This is because the carbonaria class is largely uninfluenced by the possibility of misclassification, as explained above.) We find $\chi_{(3)}^{2}=23 \cdot 64$, for which $\mathrm{P}<\mathrm{0} \cdot 00 \mathrm{I}$. Thus a very appreciable degree of heterogeneity is revealed in spite of the much smaller sample (777) now used, and this is reflected proportionately in the estimated frequencies of the typica and insularia forms which for this district vary, with comparable methods of collecting, between 18 and $4^{0}$ per cent.

Nevertheless, in spite of identification difficulties, f. insularia offers many points of considerable interest. As pointed out by Haldane (personal communication), a triangular graph of the three phenotypes (fig. 3) shows that high values of f. insularia are associated with carbonaria frequencies of from ro to 30 per cent. Districts showing this, for the most part, are centred around the Severn Watershed and Gloucestershire which, without doubt, receive constant pollution fall-out from Bristol and South Wales. Also the Isle of Man, which is subject to occasional but definite smoke drift from the industrial areas of Lancashire, when the wind is in an easterly direction, has a high insularia frequency of $3^{6}$ per cent. In those areas where carbonaria is common, the frequency of visible insularia falls, and the random sample, therefore, becomes less accurate, varying in direct proportion to an increased carbonaria frequency.

Unfortunately earlier records of f. insularia are, for the most part, lost, and what I have been able to extract is largely circumstantial. 
For example, the Giles Collection of Lepidoptera in the Folkestone Museum was amassed between the years 1880 and I89o. It was a local collection and in it is a series of 18 betularia, I 2 typica and 6 insularia. They are by appearance not bred, in fact many of both forms are worn, and it is likely that this is a small random sample, and reflects correctly a frequency of about 33 per cent. insularia at this date. Carbonaria did not appear in Folkestone until a very much later date, about 1927 (Morley, personal communication). As will be seen from table 2, the present insularia frequency is about II per cent., with carbonaria standing at 42 per cent., which gives an estimated

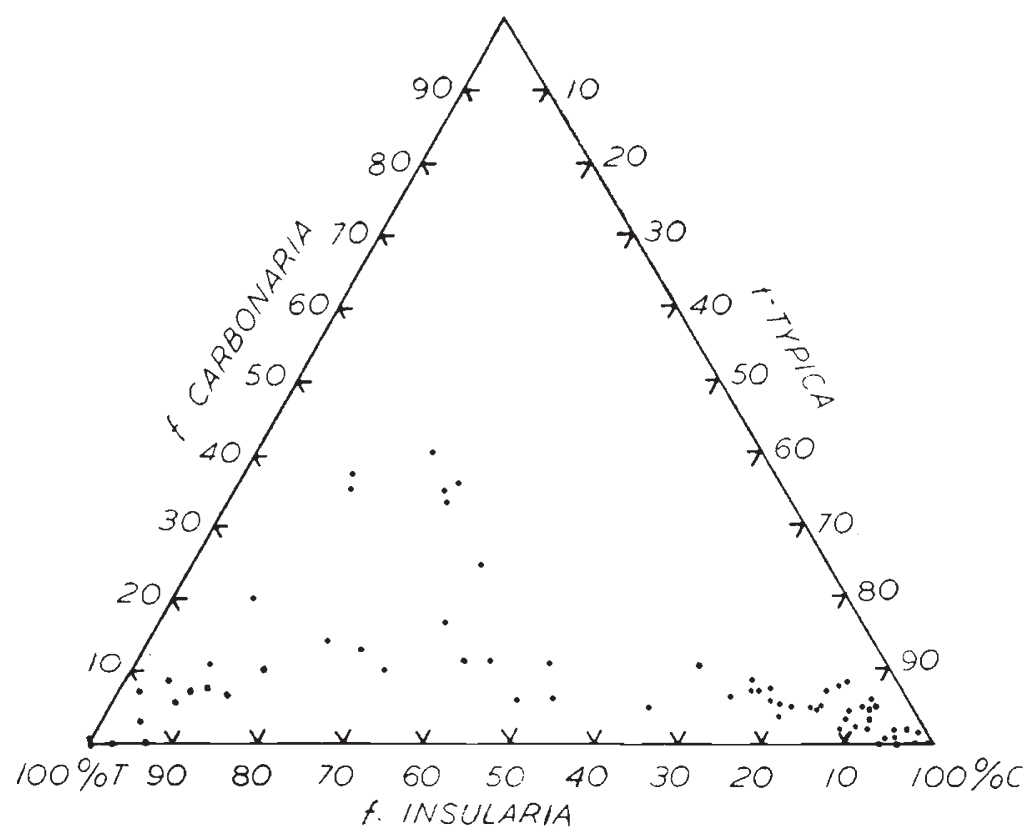

FIG. 3-Graph showing frequencies of the three phenotypes of Biston betularia in Britain.

insularia frequency, on the assumption of there being no linkage, of I 7 per cent. It has, in fact, dropped 16 per cent. in thirty years, during which time the frequency of carbonaria has risen from approximately I to 42 per cent. The true frequency of $\mathrm{f}$. typica would, therefore, have increased during this period from 66 to 83 per cent. If this is true, $\mathrm{f}$. carbonaria has expanded at the expense of $\mathrm{f}$. insularia and not f. typica and it suggests that insularia, in the presence of heterozygous carbonaria, may interact in a disadvantageous manner.

At the upper end of the carbonaria frequency, there appear to be only one set of early figures available. Arkle (Igor) took a sample of 180 betularia at electric light in Chester, and this can be compared with a sample of 124 taken during 1956 by S. Gordon Smith. In a period of over fifty years, the estimated frequency of insularia has dropped by only 7.5 per cent. in the population in spite of its cryptic 
disadvantage. Furthermore, if one includes the combined figures for Cheshire, the insularia frequency is still $22 \cdot 76$ per cent.

\begin{tabular}{|c|c|c|c|c|c|}
\hline \multicolumn{6}{|c|}{ Pcrcentage phenotypes } \\
\hline Year & $\mathrm{T}$ & C: & I & Total & $\begin{array}{l}\text { I } \\
\text { Estimated } \\
\text { frequency }\end{array}$ \\
\hline IgoI & I3 per cent. & 83 per cent. & 3 per cent. & 180 & 20 per cent. \\
\hline 1956 & ", & 93 & $0 \cdot 8 \mathrm{I}$ & 124 & $12 \cdot 5$ \\
\hline
\end{tabular}

The insularia records obtained in the last few years are a good deal more helpful. Nowhere have we so far obtained a phenotype frequency at a level higher than 40 per cent. This can be interpreted in any one of several ways. Either on every occasion f. carbonaria has swept

T.ABLE 4

Frequency of $f$. carbonaria recorded in the last four years for districts having a low carbonaria frequency

\begin{tabular}{|c|c|c|c|c|c|c|}
\hline $\begin{array}{l}\text { Locality } \\
\text { (observer) }\end{array}$ & lear & $\begin{array}{c}\text { Per cent. } \\
\underset{T}{1}\end{array}$ & $\begin{array}{l}\text { Per cent. } \\
\quad \mathrm{C}:\end{array}$ & $\begin{array}{l}\text { Per cent. } \\
\text { I }\end{array}$ & Total & $\begin{array}{l}\text { Estimated } \\
\text { insularin } \\
\text { frequency }\end{array}$ \\
\hline $\begin{array}{l}\text { Oxtord } \\
\text { (P. Sheppard) }\end{array}$ & $\begin{array}{l}195^{2} \\
1954 \\
1956\end{array}$ & $\begin{array}{l}45 \cdot 6 j \\
4{ }^{2} \cdot 50 \\
3+\cdot 82\end{array}$ & $\begin{array}{l}28 \cdot 26 \\
3+\cdot 20 \\
39 \cdot 70\end{array}$ & $\begin{array}{l}26 \cdot 09 \\
23 \cdot 50 \\
25.40\end{array}$ & $\begin{array}{r}46 \\
219 \\
224\end{array}$ & $\begin{array}{l}36 \cdot 37 \\
35 \cdot 45 \\
42 \cdot 22\end{array}$ \\
\hline $\begin{array}{l}\text { Wiltshire } \\
\text { (Marlborough } \\
\text { College) }\end{array}$ & $\begin{array}{l}19511 \\
19521 \\
1955 \\
1956\end{array}$ & $\begin{array}{l}76 \cdot 67 \\
86 \cdot 30 \\
76 \cdot 38\end{array}$ & $\begin{array}{r}1.66 \\
7 \cdot 19 \\
11 \cdot 81\end{array}$ & $\begin{array}{r}21 \cdot 67 \\
6 \cdot 48 \\
11 \cdot 81\end{array}$ & $\begin{array}{r}60 \\
139 \\
254\end{array}$ & $\begin{array}{r}22 \cdot 03 \\
6 \cdot 98 \\
13 \cdot 39\end{array}$ \\
\hline $\begin{array}{l}\text { Glos. Nailsworth. } \\
\text { (A. Richardson) }\end{array}$ & $\begin{array}{l}1952 \\
1956\end{array}$ & $\begin{array}{l}43 \cdot 14 \\
50 \cdot 75\end{array}$ & $\begin{array}{l}11 \cdot 76 \\
17 \cdot 16\end{array}$ & $\begin{array}{l}45 \cdot 10 \\
32 \cdot 09\end{array}$ & $\begin{array}{r}51 \\
134\end{array}$ & $\begin{array}{l}5^{I} \cdot \mathrm{II} \\
3^{8 \cdot 74}\end{array}$ \\
\hline $\begin{array}{l}\text { Hants, Bordon } \\
\text { (D. Wright) }\end{array}$ & $\begin{array}{l}195^{2} \\
1953 \\
1954 \\
1955\end{array}$ & $\begin{array}{l}59 \cdot 66 \\
64 \cdot 44 \\
69 \cdot 39 \\
66 \cdot 08\end{array}$ & $\begin{array}{l}21 \cdot 33 \\
19 \cdot 53 \\
18 \cdot 38 \\
22 \cdot 02\end{array}$ & $\begin{array}{l}19.01 \\
16.03 \\
12.23 \\
11.90\end{array}$ & $\begin{array}{l}647 \\
599 \\
941 \\
908\end{array}$ & $\begin{array}{l}24 \cdot 16 \\
19 \cdot 92 \\
14 \cdot 90 \\
15 \cdot 25\end{array}$ \\
\hline
\end{tabular}

This gives the following selective adrantages for $f$. carbonaria: Oxford 12.2 per ccnt., Wiltshire 44.6 per cent., Gloucestershire I2 per cent., Hampshire 2 per cent. (approx.).

through the population, an increase in pollution having taken place, thereby favouring this more extreme mutant and enabling it to overtake insularia; or, alternatively, homozygous insularia are at a considerable disadvantage to the heterozygotes. A third explanation could be that insularia has partial linkage to carbonaria, so that fewer insularia phenotypes appear in the population when the carbonaria mutant becomes common. Table 4 does, in fact, suggest, with the 
exception of Oxford, that carbonaria increases at the expense of insularia and not of f. typica.

If we assume that there is no linkage, we are able to graph the estimated frequency of insularia in any population, in which it may be to a great extent concealed by carbonaria. The higher the carbonaria frequency, however, the greater the error because of the paucity of the insularia sampled. Fig. 4 shows the result of graphing all estimated frequencies shown in table 2 in which the total sampled was larger than fifty individuals. The data suggest the following deductions :--

(I) When f. carbonaria and f. insularia simultaneously enter a population consisting of $\mathrm{f}$. typica only, f. insularia will rise to about

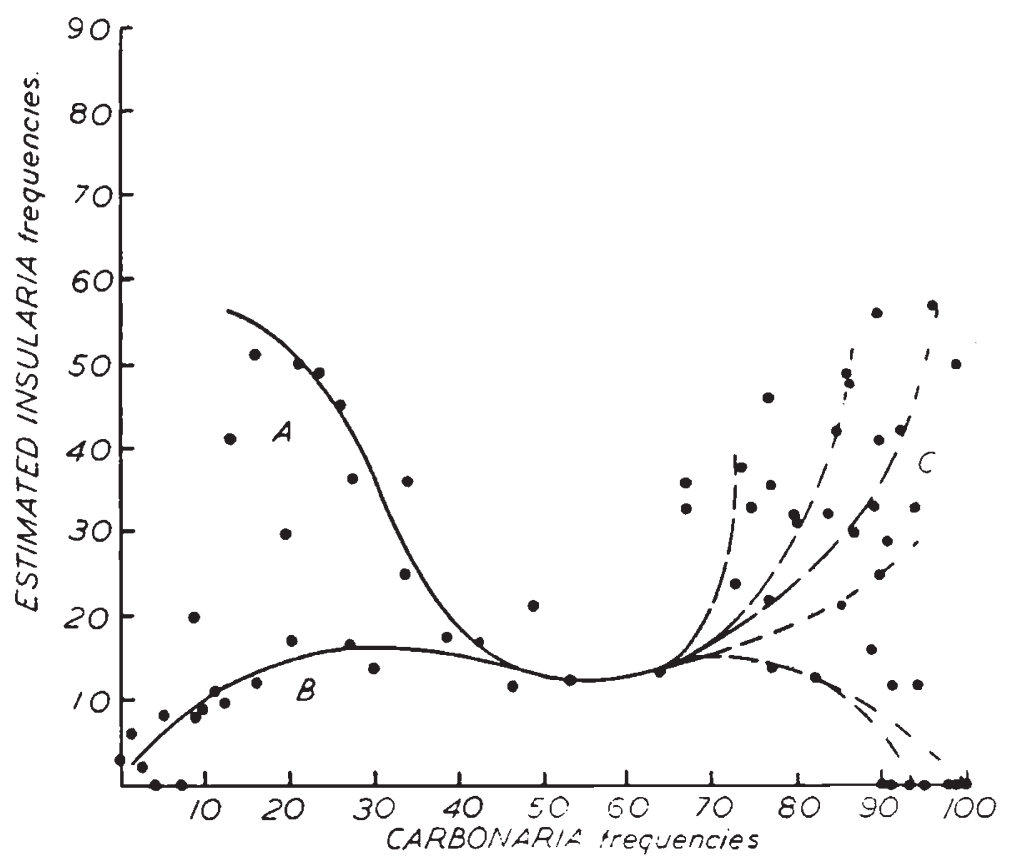

FIG. 4.-Graph showing frequencies of insularia for the majority of districts in Britain (plotted against carbonaria frequencies).

I 5 per cent., but no higher as long as the carbonaria frequency remains under to per cent. (District B).

(2) When f. carbonaria enters a population which has a high frequency of $\mathrm{f}$. insularia (40 per cent.), it is likely that this will drop to this same level of 15 per cent. (District A).

(3) Carbonaria frequencies of between 40 and 65 per cent. are associated with the lowest gene frequencies of insularia, and this coincides with the most rapid spread of $f$. carbonaria (fig. 2).

(4) Thereafter, a rising carbonaria frequency is associated with insularia frequencies varying from high to low (District $\mathrm{C}$ ). It is of interest then to find that each of the three main groupings, designated with a letter, correspond geographically with the different areas of Britain in the majority of recordings. Thus group $\mathrm{A}$, with a high 
frequency of insularia is largely constituted by the Severn Valley, Gloucestershire and Oxfordshire; group B the counties of Berkshire, Wiltshire, Hampshire and Dorset; while group $\mathrm{C}$ represents the whole of the eastern half of England from Yorkshire to London, an area which corresponds with the earlier map of carbonaria as drawn up by Adkin (1925).

For the purpose of analysis, it is convenient to divide the graph (fig. 4) into two portions : below 50 per cent. carbonaria frequency and above.

Below a 50 per cent. carbonaria frequency, it is evident that no matter at what level the insularia has been maintained in the population, the entry of carbonaria into it will canalise the insularia for a period of time at an approximate I 5 per cent. level. It is possible on the other hand that this may represent an equilibrium frequency in which $f$. insularia, in the presence of prolonged but slight pollution fall-out, is capable of adjusting itself in the population at this level in a state of balanced polymorphism. It is a more likely explanation, however, that it is in a transient state, in which carbonaria, the more extreme melanic, is replacing a less suitable one on the presence of ever-increasing air pollution. It could, however, be a further indication that insularia, in the presence of heterozygous carbonaria, is at a disadvantage.

Above a 50 per cent. carbonaria frequency (fig. 4), the estimated insularia values vary from o to 65 per cent., the majority being high except in populations practically entirely overrun by f. carbonaria, where the insularia samples are always inadequate. This can be brought about by one of two alternative ways. The initial cryptic advantage of insularia, being now largely lost in the carbonaria phenotype, it is likely that heterozygous insularia have some definite physiological advantage in the presence of homozygous carbonaria. Alternatively, it could be argued that over levels of 65 per cent. carbonaria frequencies, the insularia cryptic advantage is largely lost, and insularia would find itself floating in a carbonaria population, and subject to drift. This could constitute a new type of circumstance, allowing drift, but in my opinion it is most unlikely that insularia has a completely neutral physiological value apart from its initial cryptic advantage. Furthermore, if homozygous insularia are eliminated as seems possible, drift cannot be considered as an explanation.

Standard statistical analysis shows a highly significant degree of heterogeneity $\left(\chi_{\left(3^{8}\right)}^{2}=99 \cdot 86\right)$ in the proportions of $\mathrm{f}$. insularia in populations with over 65 per cent. carbonaria, and it is evident that f. insularia continues to maintain itself within a carbonaria population even after losing its cryptic advantages and, in fact, may even expand. On the other hand, slow elimination is indicated by the subsequent history of the only recorded early frequency known to me, which indicates that in Chester the estimated frequency of insularia has dropped 7.5 per cent. in 55 years, but the sample for this assumption is inadequate. It must be remembered that at the beginning of this 

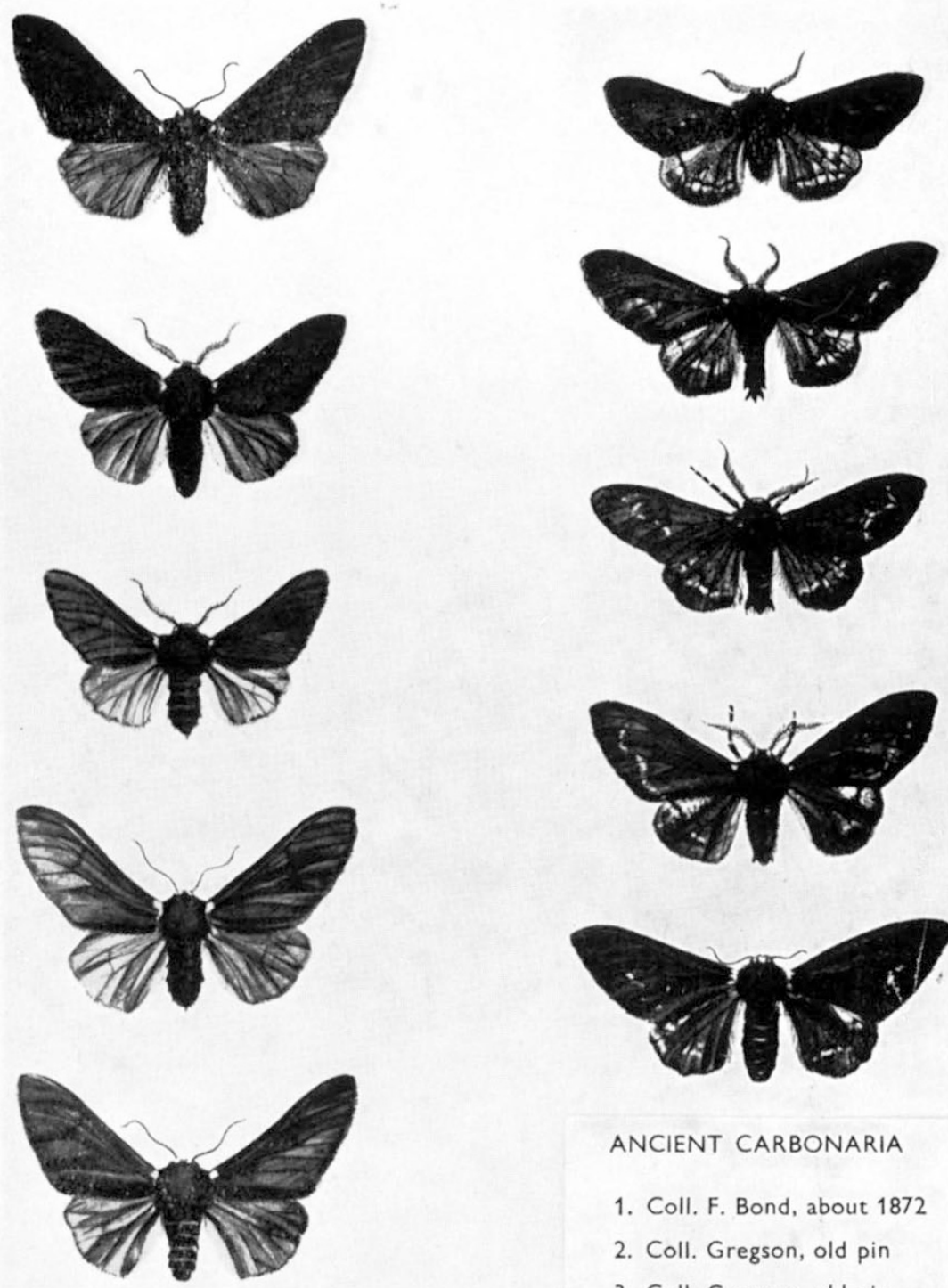

MODERN HETEROZYGOTES

OF CARBONARIA

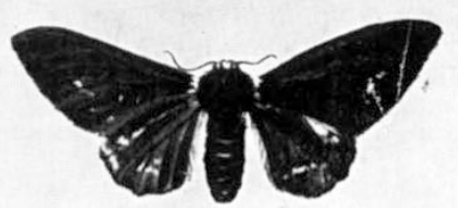

\section{ANCIENT CARBONARIA}

1. Coll. F. Bond, about 1872

2. Coll. Gregson, old pin

3. Coll. Gregson, old pin

4. Coll. Sidney Webb

5. Coll. Cooke, old pin

\section{Plate}

Ancient and modern heterozygotes of Biston betularia f. carbonaria. The former were extracted from old collections made in the last century and have many white markings. Specimens like these are but rarely found to-day.

(Photograph by John Haywood from painting by Christine Court, Oxford). 
period 3 per cent, of the population were still appearing as f. insularia which would, on most occasions, be eliminated because of their cryptic disadvantage in heavily polluted districts. Only future records will be able to settle what really happens, and their foundation is now laid in this paper. At the same time, it has served to point out that the natural history of the T-C-I complex in this rapidly changing countryside is likely to raise problems of unusual interest.

\section{SUMMARY}

I. The early history of Biston betularia and its two melanic forms in Britain, carbonaria and insularia, has been recorded. Selective advantages have been estimated for the period of over i oo years since the commencement of industrial melanism, and shown to be similar to those suggested by Haldane (I924) on the ground of theory, but slightly smaller.

2. The present survey includes over 20,000 records of betularia from many districts of Britain which have been made by over 150 observers. A table of these is given, and a frequency map has been prepared from them. The data show correlation between the industrial centres and high frequency of $\mathrm{f}$. carbonaria, the more extreme melanic. Carbonaria is also abundant throughout the eastern half of England; this is probably the result of the indirect effects of smoke-drift following the prevailing south-westerly wind. The south-western parts of England and the whole of northern Scotland are free of melanics.

3. The rate of spread of carbonaria follows a sigmoid curve. The original light form is maintained at a very low frequency in all industrial populations. This may eventually lead to a balanced polymorphism if the heterozygous carbonaria are at an advantage to either homozygote.

4. The highest phenotype frequencies of insularia are found in populations having io to 30 per cent. carbonaria, and these are for the most part centred around the Severn Watershed, Gloucestershire and Oxfordshire. Insularia phenotype never occurs higher than 40 per cent., and this may be because the homozygote is at a disadvantage.

5. A graph, showing the estimated frequencies of insularia, has been prepared. It has been shown that carbonaria, when between 20 and 50 per cent. of the population, expands at the expense of insularia but not of $\mathrm{f}$. typica.

6. In populations of more than 65 per cent. carbonaria, the insularia gene frequency may be either high or low, in spite of ever increasing loss of its carlier cryptic advantages.

7. This paper is intended to be a foundation for future records which may disclose the true behaviour of two dominant genes both rapidly and simultaneously spreading through a population. 
Acknowledgments.-I wish to thank all the observers without whose help this paper would not have been possible. I am grateful to the Nuffield Foundation who have enabled me to undertake this work. I am indebted to Professor J. B. S. Haldane, F.R.S., for hclpful suggestions and for the privilege of his analysis of this paper. Also to Dr P. M. Sheppard who has not only contributed records of his own, but has given me much advice. I have greatly benefited from the co-operation of Dr E. B. Ford, F.R.s., also Dr A. J. Cain and Mr M. H. Williamson. I would like to thank Miss Christine Court for her help in the preparation of maps and graphs, and Mr John Haywood for his photography.

\section{REFERENCES}

ADKIN, R. 1925-26. Melanism in the Lepidoptera. Some theories and some examples. Proc. S. Lond. Ent. Nat. Hist. Soc., pp. 7-2 1.

BARrett, C. G. I 901 . B. betularia. British Lepidoptera, 7, 127-134.

DONCASTER, L. 1906. Collective inquiry as to progressive melanism in the Lepidoptera. Ent. Rec., I8, $165-254$.

Fisher, R. A. 1937. The wave of advance of advantageous genes. Ann. Eugen., $7,360$.

H.ALANE, J. B. S. 1924. A mathematical theory of natural and artificial selection. Trans. Ciam. Phil. Soc., 23, 26.

KETTLEWELL, H. B. D. 1955. Selection experiments on industrial melanism in the Lepidoptera. Heredity, $9,323-34^{2}$.

KettLewell, H. B. D. 1956. Further selection experiments on industrial melanism in the Lepidoptera. Heredity, Io, 287-301.

KETTLEWELL, H. B. D. 1956 . A résumé of investigations on the evolution of melanism in the Lepidoptera. P.R.S. B., 145. 297-303.

MERA, A. W. 1925. Incrcase in melanism in the last half-century. The Lond. $\mathcal{N a t . .}$ pp. 3-9. 